\title{
PENERAPAN DECISION MAKING UNTUK MENINGKATKAN HASIL BELAJAR PADA MATA PELAJARAN AKUNTANSI
}

\author{
Oleh: Khristina Sri Prihatin \\ Universitas Banten Jaya \\ Serang, Indonesia \\ khristinasriprihatin@unbaja.ac.id
}

\begin{abstract}
This study was aimed to determine: 1) application of decision making learning model in class XI MA at Daar El- Istiqomah Sukawana, Serang city of Banten, academic year 2016/2017. 2) The improvement of the results of accounting learning by applying decision making learning model on the subject matter of Recording Transactions/ Documents into General Jurnal in class XI MA at Daar El-Istiqomah, Sukawana, Serang - Banten City in academic year 2016/2017.This research was a classroom action research (CAR). The research used two cycles and each cycle consisted of four steps. The subjects in this study was class XI in MA Daar El-Istiqomah Sukawana, Serang - Banten, that consist of 25 students. The object of this research was an implementation of decision making learning model.The results showed that the implementation of decision making learning model could be increased teacher and students activity. It could be seen that there were an increasing activity from cycle 1 to cycle 2. On cycle I, based on teacher observation, the activity reached $58 \%$ and in cycle II reached $88 \%$. Students learning outcomes based on average pre test reached 45 . While the post test on cycle 1 by applying the Decision Making learning model has increased 71.4, and the average in post test on cycle II increased quite significant than in cycle 1 that is 80,8 .
\end{abstract}

Key words: Decision Making Learning Model, Learning Outcomes, MA Accounting.

\section{PENDAHULUAN}

Pendidikan merupakan salah satu faktor yang sangat penting di dalam rangka meningkatkan pembangunan di suatu Negara. Karena pendidikan menciptakan sumber daya manusia atau sumber daya insani untuk mendorong lajunya tingkat pembangunan. Apabila di dalam suatu Negara pendidikan tersebut dapat menghasilkan manusia yang berpotensi, kreatif serta memiliki akhlak yang baik, tidak dapat dipungkiri lagi pembangunan akan terlaksana melalui anak-anak bangsa tersebut. Dapat dikatakan, melalui pendidikan diharapkan mampu dikembangkan kemampuan untuk dapat memenuhi kebutuhan kerja masa sekarang. Sehingga, dengan pendidikan dapat terciptanya manusia yang yang cerdas dan berakhlak baik sesuai dengan etika dan norma-norma agama yang berdasarkan UUD 1945 dan Pancasila.

Untuk mewujudkan tujuan pendidikan Sebagaimana yang tercantum dalam Undang-undang nomor 20 tahun 2003 dalam bab II Pasal 3 tentang fungsi dan tujuan pendidikan nasional disebutkan bahwa pendidikan nasional bertujuan untuk mengembangkan kompetensi dan membentuk watak dan perdaban suatu 
bangsa yang memiliki martabat untuk dapat mencerdaskan kehidupan bangsa. Pendidikan berfungsi untuk mengembangkan potensi peserta didik agar dapat menjadi masnuai yang beriman dan bertaqwa kepada Allah SWT, memiliki ahlak yang baik, cerdas, sopan da santun serta dapat memberikan manfaat baik tenaga dan pikirannya demi kemajuan negaranya.

Agar menghasilkan sumber daya yang berkualitas diperlukan model pendidikan yang tidak hanya mampu menjadikan peserta didik cerdas dalam teoritical science (teori ilmu), tapi juga cerdas practical science (praktik ilmu). Dalam memberikan Pendidikan era jaman sekarang, bukan saja ilmu pengetahuan yang diberikan tetapi lebih kepada pendidikan yang beretika, sehingga seorang pendidik mampu memasukkan unsur-unsur akhlak dalam memberikan ilmu pengetahun. Seorang pendidik adalah ujung tombak dalam melaksanakan misi pendidikan di lapangan serta merupakan faktor penting dalam mewujudkan sistem pendidikan yang bermutu dan efisien sehingga dalam kegiatan belajar mengajar guru berperan sangat penting untuk mencapai tujuan pembelajaran. Guru sebagai tenaga pengajar semestinya mampu mentransformasikan ilmunya kepada anak didik, Untuk memperbaiki mutu pendidikan, guru dituntut lebih kreatif dalam menyampaikan pembelajaran sehingga mampu menciptakan inovasiinovasi baru.

Inovasi merupakan suatu aplikasi metode baru yang dapat diimplementasikan, yang belum pernah dilakukan dalam metode pengajaran manapun. Sehingga bentuk inovasi pembelajaran ini menjadikan hal yang sangat penting dari pola pengajaran yang lama berubah ke pola pengajaran yang baru. Dimana pola pengajaran yang hanya dilakukan Guru di depan kelas dengan metode ceramah, dapat berubah dengan pola inovasi-inovasi pembelajaran yang guru miliki. Adanya upaya dari guru untuk mencari berbagai variasi pendekatan, model dan strategi pembelajaran merupakan salah satu upaya yang dapat menunjang adanya inovasi baru di kelas.

Pada pelajaran akuntansi, materi berisi proses-proses transaksi dan menghitung. Sehingga peserta didik berpikir bahwa materi akuntansi akan rumit dan membosankan, yang menyebabkan hasil belajar menjadi tidak optimal. Hal tersebut terbukti pada saat dilakukan observasi di MA Daar ElIstiqomah proses pembelajaran peserta didik cenderung hanya mendengar saja tanpa ada ketertarikan untuk mengetahui lebih dalam lagi. Sehingga pada saat 
diadakan tanya jawab peserta didik cenderung pasif tidak berfikir secara kritis untuk dapat memecahkan masalah sehingga guru harus mengulang kembali dan menyita banyak waktu yang akan membuat belajar menjadi tidak kondusif, sehingga tercipta suasana belajar yang tidak menyenangkan.

Dari Dokumentasi yang diperoleh peneliti di kelas XI MA Daar El-Istiqomah tahun ajaran 2016/2017, nilai rata-rata belum memenuhi KKM (Kriteria Ketuntasan Minimal) mata pelajaran Akuntansi yaitu sebagai berikut:

Tabel 1. Hasil Belajar Akuntansi

\begin{tabular}{|c|c|c|c|c|c|}
\hline $\begin{array}{l}\text { Jumlah } \\
\text { Siswa }\end{array}$ & KKM & $\begin{array}{l}\text { Mencapai } \\
\text { Ketuntasan }\end{array}$ & $\%$ & $\begin{array}{l}\text { Belum } \\
\text { mencapai } \\
\text { ketuntasan }\end{array}$ & $\%$ \\
\hline 25 & 70 & 11 & $44 \%$ & 14 & $56 \%$ \\
\hline
\end{tabular}

Sumber: Data yang diolah 2017

Dengan melihat kondisi hasil belajar yang tidak optimal, peneliti berusaha mencari solusi untuk mengatasi masalah tersebut. Metode- metode pembelajaran banyak sekali yang dapat digunakan dalam meningkatkan kualitas hasil belajar. Salah satu alternatif model pembelajaran yang dapat digunakan untuk menyelesaikan masalah yang terdapat dilatar belakang masalah adalah model pembelajaran decision making . Menurut Dewey (dalam Depdiknas 2004 : 12) menyatakan bahwa, ada tiga strategi dalam model pembelajaran decision making yaitu: Berpikir kritis (critical thinking), pemecahan masalah (problem solving), berpikir logis (logical thinking) dengan menerapkan metode pembelajaran decision making ini, maka diharapkan dapat memberikan suasana baru dalam pembelajaran akuntansi sehingga dapat meningkatkan hasil belajar siswa.

Menurut Dewey (dalam Depdiknas 2004: 12) menyatakan bahwa, Model Pembelajaran Decision Making tidak jarang disamakan dengan berpikir kritis, pemecahan masalah dengan berpikir logis serta berpikir selektif.

1. Berpikir kritis (critical thinking) artinya untuk sampai suatu kesimpulan diawali dengan pertanyaan dan pertimbangan kebenaran serta nilai apa yang sebenarnya ada dalam pertanyaan itu.

2. Pemecahan masalah (problem solving) artinya untuk sampai pada kesimpulan diawali dengan masalah yang dihadapi dan mempertanyakan bagaimana masalah itu dapat diselesaikan/dipecahkan.

3. Berpikir logis (logical thinking) untuk sampai pada suatu kesimpulan yang diutamakan adalah alur berpikirnya, mulai identifikasi, menganalisis fakta dan opini serta aplikasinya dalam kehidupan sehari-hari. 
Dari ketiga pemikiran tersebut semuanya bermuara pada pengambilan keputusan untuk mendapatkan suatu pilihan yang kemudian ditindaklanjuti dalam bentuk tindakan.

Menurut Syah (2011 : 20) Pengambilan Keputusan jika dilihat dari cara memperoleh informasi dapat dikategorikan menjadi empat.

Keempat kategori tersebut yaitu keputusan representasi, empiris, informasi, ekspolorasi. Adapun penjelasan dari keempatnya sebagai beikut.

1. Keputusan Representasi merupakan keputusan yang dihadapi dengan informasi yang cukup banyak, dan mengetahui dengan tepat bagaimana memanipulasi informasi dalam pembelajaran.

2. Keputusan Empiris merupakan keputusan yang kurang memiliki informasi namun mengetahui bagaimana memperoleh informasi dan pada saat informasi itu diperoleh dinamakan keputusan empiris.

3. Keputusan Informasi merupakan keputusan yang kaya akan informasi, tetapi diliputi dengan kontroversi tentang bagaimana memperoleh informasi itu, dan selanjutnya akan menghasilkan keputusan informasi.
4. Keputusan Ekpolorasi Merupakan keputusan yang kurang akan informasi dan tidak ada kata sepakat yang dianut untuk memulai mencari informasi serta tidak tahu darimana usaha pengambilan keputusan akan dimulai.

Sementara itu menurut Sapriya (2015:152). Makna konsep pengambilan keputusan (decision making) berkaitan dengan kemampuan berpikir tentang alternatif pilihan yang tersedia, menimbang fakta dan bukti yang ada, mempertimbangkan tentang nilai pribadi dan masyarakat.

Menurut Mulyono (2008: 1) menyatakan bahwa, dapat disimpulkan pengambilan keputusan (decision making) diartikan sebagai pemilihan alternatif terbaik dari beberapa pilihan yang tersedia sebagai suatu cara dalam pemecahan masalah. Dapat disimpulkan, untuk mengambil keputusan tidak hanya bertujuan untuk mendapatkan informasi namun juga dilandasi oleh pertimbangan logis serta penilaian yang mendalam, sehingga tindakan yang akan diambil dapat dipertanggungjawabkan. Pengambilan keputusan yang efektif membutuhkan keterampilan mengumpulkan informasi tentang suatu permasalahan, berpikir kritis dan kreatif.

Cara menentukan kelompok Model Cooperative Learning Tipe Pengambilan 
Keputusan (Decision Making) menurut

Depdiknas (2004 : 7) adalah:

1. Jumlah anggota tiap kelompok terdiri dari 5 orang.

2. Pengelompokan siswa hendaknya heterogen.

3. Penetapan kelompok ditentukan oleh pendidik.

4. Penghargaan (hadiah) lebih berorientasi kepada kelompok dari pada individu.

$$
\text { Menurut Mulyono }
$$

menyatakan bahwa, kelebihan dari model Cooperative Learning Tipe Pengambilan

Keputusan (Decision Making) yaitu:

1. Menghilangkan sifat mementingkan diri sendiri atau egois.

2. Meningkatkan kesetiakawanan sosial.

3. Meningkatkan kesediaan menggunakan ide orang lain yang dirasakan lebih baik.

4. Memungkinkan para siswa saling belajar mengenai sikap, keterampilan informasi, perilaku sosial, dan pandang- pandangan.

5. Meningkatkan kegemaran berteman tanpa memandang perbedaan kemampuan, jenis kelamin, normal atau cacat, kelas sosial, agama, dan orientasi tugas.

Menurut Lie (2002 : 47) menyatakan bahwa Kekurangan model
Cooperative Learning Tipe Pengambilan Keputusan (Decision Making) yaitu:

1. Membutuhkan lebih banyak waktu.

2. Membutuhkan sosialisasi yang lebih baik.

3. Siswa mudah melepaskan diri dari keterlibatan dan tidak memperhatikan.

4. Kurang kesempatan untuk individu.

5. Sering terjadi kegaduhan.

Langkah - langkah Model Pembelajaran Decision Making Menurut Fatimah et al (2008:17) dalam skripsi Diani (2015). langkah-langkah Model Cooperative Learning Tipe Pengambilan Keputusan (Decision Making) sebagai berikut:

1. Memberikan informasi, tujuan, dan rumusan masalah.

2. Secara klasikal tayangan gambar, wacana atau kasus permasalahan yang sesuai dengan materi pembelajaran atau kompetensi yang diharapkan.

3. Buatlah pertanyaan agar siswa dapat meru muskan permasalahan sesuai dengan gambar, wacana atau kasus yang disajikan.

4. Secara kelompok siswa diminta mengidentifikasikan permasalahan dan membuat alternatif pemecahannya.

5. Secara kelompok/individu siswa diminta mengidentifikasi permasalahan yang terdapat di lingkungan sekitar 
siswa yang sesuai dengan materi yang dibahas dan cara pemecahannya.

6. Secara kelompok/individu siswa diminta mengemukakan alasan mereka memilih alternatif tersebut.

7. Secara kelompok/individu siswa diminta mencari penyebab terjadinya masalah tersebut.

8. Secara kelompok/individu siswa diminta mengemukakan tindakan untuk mencegah terjadinya masalah tersebut.

Dapat disimpulkan langkah langkah model pembelajaran Decision Making tersaji pada tabel sebagai berikut:

Tabel 2. Langkah-langkah Model Pembelajaran Decision Making

\begin{tabular}{|c|c|c|}
\hline No & $\begin{array}{l}\text { Langkah } \\
\text { Decision } \\
\text { Making }\end{array}$ & Perlakuan Guru \\
\hline 1 & Informasi & $\begin{array}{l}\text { Pada tahap ini guru } \\
\text { memberikan } \\
\text { informasi, tujuan dan } \\
\text { rumusan masalah. }\end{array}$ \\
\hline 2 & $\begin{array}{c}\text { Merumuskan } \\
\text { Masalah }\end{array}$ & $\begin{array}{l}\text { Pada tahap ini guru } \\
\text { mengajak siswa untuk } \\
\text { merumuskan masalah } \\
\text { sesuai dengan gambar } \\
\text { dan alat peraga yang } \\
\text { disajikan. }\end{array}$ \\
\hline 3 & Indentifikasi & $\begin{array}{l}\text { Pada tahap ini guru } \\
\text { meminta siswa untuk } \\
\text { mengidentifikasi } \\
\text { permasalahan yang } \\
\text { terdapat dilingkungan } \\
\text { sekitar dan membuat } \\
\text { alternatif pemecahan } \\
\text { masalah secara } \\
\text { kelompok. }\end{array}$ \\
\hline
\end{tabular}

\begin{tabular}{cclr}
\hline & & \multicolumn{2}{l}{ Pada tahap ini guru } \\
& mengajak siswa untuk \\
& berfikir real, \\
& mengajak siswa untuk \\
& Masalah & mengemukakan \\
& memilih alternatif, \\
& dan mencari \\
& penyebab terjadinya \\
& masalah. \\
& Pada tahap ini guru \\
& mengajak siswa untuk \\
& menyimpulkan \\
Merumuskan & seluruh informasi \\
& Kesimpulan & yang telah diperoleh \\
& dan memberi \\
& penghargaan. \\
\hline
\end{tabular}

\section{METODE PENELITIAN}

Tempat penelitian yang akan diteliti berlokasi di sekolah MA Pondok Pesantren Modern Daar El-Istiqomah Sukawana Kota Serang Banten

Penelitian tindakan kelas ini bermaksud meminimalkan kesalahan siswa dalam memahami materi Akuntansi. Sebagai tahap awal sebelum mengadakan penelitian dilakukan observasi dan tes awal (pre test) untuk mengetahui kemampuan awal siswa. Hasil observasi dan tes tersebut dijadikan pedoman awal untuk mengetahui tindakan yang akan dilaksanakan. Penelitian ini dilaksanakan dalam 2 siklus, setiap siklus terdiri dari 4 tahap, yaitu perencanaan, pelaksanaan tindakan, pengamatan dan refleksi. Secara rinci urutan masing-masing tahap dapat dilihat digambar 1 berikut ini: 


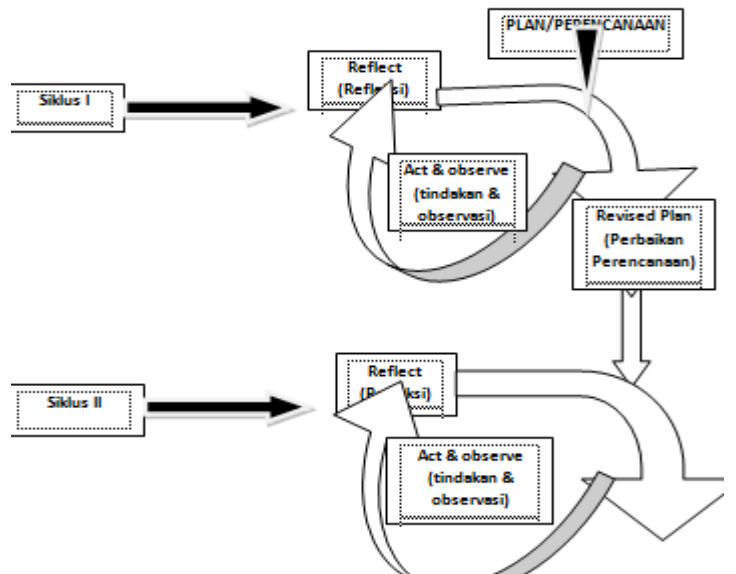

Gambar 1. Model Penelitian Tindakan Kelas model Kemmis dan Mc Tagart (Prof. Dr. H.Tukiran Taniredja et al, 2013:24)

Memecahkan masalah dalam penelitian diperlukan data yang relevan dengan permasalahannya, sedangkan untuk mendapatkan data tersebut perlu digunakan teknik pengumpulan data sehingga dapat diperoleh data yang benar-benar valid dan dapat dipercaya. Teknik pengumpulan data yang digunakan dalam penelitian ini, antara lain dengan menggunakan

1. Tes

Tes adalah instrument atau alat yang digunakan untuk mengetahui informasi pengetahuan seseorang, dengan cara mengajukan sejumlah pertanyaan yang di sampaikan pada seseorang atau kelompok untuk mengungkapkan keadaan atau tingkat perkembanggan salah satu atau beberapa aspek psikologis di dalam dirinya. Aspek psikologis itu dapat berupa prestasi atau hasil belajar, minat, bakat, sikap, kecerdasan, reaksi motorik, dan berbagai aspek keperibadian lainnya.
Penelitian yang menggunakan metode tes ini untuk mengetahui sejauh mana responden dalam memiliki ilmu pengetahuan yang diajarkan oleh pendidik, sebelum peneliti menerapkan model Decision Making, dimana tes tersebut adalah pre test. Dan setelah peneliti menerapkan metode Decision Making maka tes yang dilakukan adalah post tes.

\section{Observasi}

Observasi adalah salah satu teknik pengumpulan data dengan cara mengamati, memantau, melihat dan mencatat kejadiankejadian secara sistematis dan berkala, dengan menggunakan alat tulis untuk mencatat, video, kamera, handphone untuk merekam, sehingga dapat diketahui apabila ada kejadian-kejadian yang berbeda dengan sebelumnya.

3. Wawancara

Wawancara adalah proses memperoleh keterangan untuk tujuan penelitian dengan cara tanya jawab, sambil bertatap muka antara pewawancara dengan responden. Digunakan untuk mewawancarai siswa mengenai kesulitan pada penyampaian meteri pelajaran sehingga mendapatkan gambaran kegiatan pembelajaran yang akan dilangsungkan.

4. Dokumentasi

Menurut kamus Bahasa Indonesia dari dinyatakan bahwa, dokumentasi 
adalah suatu cara yang dilakukan untuk menyediakan dokumen - dokumen dengan menyertakan bukti yang akurat dari pencatatan sumber - sumber informasi baik yang berasal dari tulisan atau karangan, buku, undang- undang dan sebagainya. Teknik dokumentasi digunakan untuk mendapatkan keterangan dan penerangan pengetahuan dan bukti.

\section{HASIL PENELITIAN DAN} PEMBAHASAN

Pada pelaksanaannya, penelitian ini dilakukan dalam dua siklus, dari kedua siklus yang telah dilaksanakan terlihat adanya peningkatan hasil belajar siswa dengan model pembelajaran Decision Making. Hal tersebut diperkuat juga dengan peningkatan aktivitas siswa dari siklus ke siklus. Tes hasil belajar diberikan kepada siswa sebanyak tiga kali yaitu pre test satu kali yang diberikan pada siklus 1 pertemuan pertama sebelum mempraktekkan model pembelajaran Decision Making dan post test dua kali yang diberikan di akhir masing-masing siklus setelah selesai mempaktekkan model pembelajaran Decision Making.

Pada pelaksanaan siklus I terdapat beberapa kendala yang dialami oleh siswa, diantaranya pada saat melakukan diskusi, banyak siswa lebih mengandalkan temannya yang pintar dan aktif, dan siswa pun terdengar masih sangat gaduh ketika guru menjelaskan manfaat pembelajaran dan langkahlangkah pengamatan. Hal ini tejadi karena siswa belum terbiasa dan belum menyukai model Decision Making. Berdasarkan hasil deskripsi dari penelitian dapat digambarkan bahwa proses pembelajaran dengan diterapkannya model pembelajaran Decision Making untuk meningkatkan hasil belajar siswa di MA Daar ElIstiqomah mengalami peningkatan, hal ini dapat dilihat pada tiap siklusnya telah mengalami peningkatan pada siklus I dengan diterapkannya model pembelajaran Decision Making memperoleh nilai $\quad 68 \%$ dan pada siklus II memperoleh nilai $80,8 \%$.

Hal ini diperkuat oleh rata-rata hasil pre test pada siklus 1 yaitu 45 yang masuk pada kategori kurang dalam kriteria keberhasilan siswa, hasil ini belum bagus karena tidak sesuai dengan jumlah siswa yang mampu mencapai kriteria ketuntasan minimal yaitu 70, sedangkan untuk ratarata post test siklus I yaitu 71,4 yang masuk pada kategori baik dengan jumlah siswa yang sudah mencapai ketuntasan belajar sebanyak 17 siswa dan 8 siswa yang belum mencapai ketuntasan belajar. Hasil ini belum mencapai indikator keberhasilan karena belum sesuai dengan jumlah siswa yang mampu mencapai $80 \%$ 
dari jumlah siswa yang ada di kelas tersebut. Sedang untuk rata-rata hasil post test pada siklus II mencapai 80,8 yang masuk pada kategori sangat baik dengan jumlah siswa yang mencapai ketuntasan belajar sebanyak 22 siswa dan siswa belum mencapai ketuntasan belajar yang telah ditetapkan untuk kriteria keberhasilan siswa. Hasil ini sudah baik karena sudah sesuai dengan jumlah siswa yang mampu mencapai kriteria ketuntasan minimal yaitu 70 dan indikator keberhasilan yaitu $80 \%$ dari jumlah siswa yang ada dikelas tersebut. Berikut tabel rekapitulasi nilai hasil pre test dan post test.

Tabel 3. Rekapitulasi Nilai Rata-Rata Pre Test, Post Test Siklus I dan II

\begin{tabular}{lll}
\hline No & Jenis Tes & Nilai \\
\hline 1 & Pre test siklus I & 45 \\
2 & Post test siklus I & 71,4 \\
3 & Post test siklus II & 80,8 \\
\hline
\end{tabular}

Sumber: Data yang diolah 2017

Berdasarkan tabel tersebut, dapat dilihat bahwa peningkatan hasil belajar siswa masuk pada kategori sangat baik untuk kriteria keberhasilan siswa, dilihat dari perbedaan nilai rata-rata pre test siklus I yang memperoleh nilai 45, post test siklus I memperoleh nilai 71,4 dan post test siklus II memperoleh nilai 80,8. Dengan demikian perbedaan hasil belajar siswa tiap siklus meningkat sehingga kegiatan penelitian ini ada perubahan yang mempengaruhi hasil belajar siswa. Peningkatan hasil belajar siswa pada pre test dan post tes siklus I dan II adalah bukti bahwa dengan penerapan model pembelajaran Decision Making dapat meningkatkan hasil belajar siswa.

Pada pre test siklus I nilai minimum yang diperoleh siswa adalah 35 sedangkan nilai maksimal yang diperoleh siswa adalah 65 dengan jumlah nilai ratarata kelas sebesar 45 yang masuk dalam kategori kurang untuk kriteria ketuntasan belajar yang berarti masih jauh di bawah standar KKM. Hasil Belajar siswa pada post test siklus I dengan nilai minimum yang diperoleh siswa adalah 50 dan nilai maksimal yang diperoleh oleh siswa adalah 85 dengan rata-rata kelas yang diperoleh adalah 71,4 yang masuk pada kategori cukup berdasarkan kriteria keberhasilan siswa, sedangkan hasil belajar post test pada siklus II nilai minimum yang diperoleh siswa sebesar 60 dan nilai maksimal 100 dengan rata-rata kelas sebesar 81,8 yang masuk dalam kategori sangat baik berdasarkan kriteria keberhasilan siswa.

Berdasarkan data diatas dengan meningkatnya hasil belajar maka dapat disimpulkan bahwa penerapan model pembelajaran Decision Making pada kegiatan penelitian ini dianggap berhasil. 
Tabel 4. Rekapitulasi Penilaian Tindakan Kelas Guru Siklus I, Siklus II

\begin{tabular}{lll}
\hline No & Penilaian & Nilai \\
\hline $\mathbf{1}$ & siklus I & $\mathbf{5 8 \%}$ \\
$\mathbf{2}$ & siklus II & $\mathbf{8 8 \%}$
\end{tabular}

Sumber: Data yang diolah 2017

Berdasarkan tabel tersebut, dapat dilihat bahwa penilaian penelitian tindakan kelas untuk guru mengalami peningkatan, dilihat dari perbedaan nilai yang diperoleh setiap siklus mengalami kenaikan, pada siklus I memperoleh nilai $58 \%$ yang mengindikasikan bahwa penilaian penelitian tindakan kelas guru masuk dalam kategori kurang, dan pada siklus II memperoleh nilai $88 \%$ yang mengindikasikan bahwa penilaian penelitian tindakan kelas guru masuk dalam kategori sangat baik. Dengan demikian, perbedaan pelaksanaan pembelajaran terhadap guru tiap siklus meningkat.

\section{KESIMPULAN DAN SARAN}

Dari hasil penelitian dan pembahasan yang telah dilakukan tentang peningkatan hasil belajar siswa melalui model pembelajaran Decision Making, maka dapat disimpulkan bahwa:

1. Penerapan Model Pembelajaran Decision Making

Penerapan model pembelajaran Decision Making pada materi pokok
Mencatat transaksi/dokumen kedalam jurnal umum kelas XI MA Daar ElIstiqomah Tahun Ajaran 2016/2017 diterapkan dengan langkah sebagai berikut:

a. Pada kegiatan awal penggunaan model pembelajaran Decision Making, Siswa di ajarkan tiga keterampilan dasar pada model pembelajaran Decision Making, yang meliputi berpikir kritis (critical thinking), pemecahan masalah (problem solving), berpikir logis (logical thinking) siswa mendengarkan penjelasan guru terlebih dahulu, merangkum dari penjelasan guru, mengajukan pertanyaan, menyelesaikan studi kasus/kasus soal, memberikan jawaban serta alasan mengapa dapat di temukannya jawabann tersebut. dan mengklarifikasi. Setelah selesai seorang siswa wakil dari kelompoknya diminta untuk menuliskan hasil dari soal yang di berikan kemudian menjelaskan mengapa di temukan jawaban tersebut, serta menanggapi pertannyaan dari temen nya yang masih belum paham. Guru membantu siswa dan kelompok serta mengklarifikasi hal-hal yang sulit.

b. Proses penerapan model pembelajaran Decision Making mengalami peningkatan dari siklus I ke siklus II, hal ini di tunjukkan dari observasi 
aktivitas guru pada siklus I mencapai $58 \%$ yang mengindikasikan penilaian aktivitas guru masih dalam kategori kurang. Pada siklus II mengalami peningkatan sebesar $30 \%$ menjadi $88 \%$ yang mengindikasikan aktivitas guru dalam kategori sangat baik. Hal ini menunjukkan bahwa guru mampu menerapkan model pembelajaran Decision Making. Dengan demikian proses pembelajaran dengan penerapan model pembelajaran Decision Making tiap siklusnya mengalami peningkatan sehingga berpengaruh pada hasil belajar siswa.

2. Hasil Belajar Siswa

Peningkatan hasil belajar siswa melalui model pembelajaran Decision Making pada mata pelajaran Akuntansi sangat baik karena dengan menggunakan model pembelajaran Decision Making memudahkan siswa dalam memahami pelajaran. Pada awalnya siswa tidak terlalu tertarik pada pelajaran Akuntansi karena dinilai pelajaran Akuntansi itu rumit, membosankan dan menjenuhkan serta tidak menyenanngkan, sehingga banyak siswa yang bermalas-malasan untuk mengikuti kegiatan belajar di kelas.

Hasil belajar siswa dengan menerapkan model pembelajaran Decision Making terlihat meningkat dari siklus I ke siklus II, hal ini ditunjukkan dari ketuntasan belajar siswa pada siklus I mencapai $68 \%$ dengan jumlah siswa yang tuntas belajar sebanyak 17 siswa dari 8 siswa dan nilai rata-rata siswa sebesar 71,4. Hasil ini belum mencapai indikator keberhasilan siswa yaitu $80 \%$. Ketuntasan belajar siswa pada post test siklus II meningkat sebesar $20 \%$ yaitu mencapai $88 \%$ dengan jumlah 22 siswa yang tuntas belajar dari 25 siswa dan 3 siswa yang belum tuntas, hasil belajar siswa pada siklus II meningkat dengan rata-rata mencapai 80,8. Hasil belajar telah tercapai karena telah memenuhi kriteria ketuntasan minimal yang telah ditentukan yaitu 70 dan indikator keberhasilan siswa yaitu $80 \%$ dari jumlah siswa yang ada di kelas tersebut.

Berdasarkan proses dan hasil penelitian yang telah dilakukan maka penulis memiliki beberapa saran yang kiranya bermanfaat bagi pihak-pihak yang terkait, diantaranya :

1. Bagi guru hendaknya dapat menggunakan model pembelajaran yang lebih variatif, sehingga banyak pilihan untuk diterapkan sesuai dengan materi, kopetensi dasar, karaktristik siswa, serta sarana prasarana, karena model 
pembelajaran dapat mempengaruhi

hasil dari proses pembelajaran.

2. Bagi siswa, alangkah baiknya belajar aktif jadi tidak hanya mendengarkan guru tapi mampu menyelesaikan berbagai permasalahan soal yang di berikan dan mampu memberikan penjelasannya, serta siswa mampu berpikir kritis, mampu memecahkan masalah dan mampu berpikir logis.

3. Pihak sekolah hendaknya lebih memperhatikan sarana prasarana, kebutuhan yang medukung kegiatan pembelajaran khususnya akuntansi.

4. Perlu adanya penelitian lebih lanjut untuk memperoleh hasil yang signifikan serta dapat mengembangkan suatu pengetahuan.

\section{DAFTAR PUSTAKA}

Abdullah Sani, Ridwan. (2013). Inovasi Pembelajaran. Jakarta: Bani Aksara.

Arifin, Zainal (2011). Evaluasi Pembelajaran. Bandung: PT Remaja Rosdakarya.

Arikunto, Suharsimi. (2013). Prosedur Penelitian Suatu Tindakan Praktik. Jakarta: Rineka Cipta.
Departemen Pendidikan Nasional. 2004. Pengetahuan Sosial. Jakarta.

2006

Jakarta.

Fatimah, et. al. (2008). Model-model Pembelajaran (SMA/SMP). Palembang: Pendidikan dan Profesional Guru Rayon 4 Universitas Sriwijaya.

Hamalik, Oemar. (2009). Perencanaan Pengajaran Berdasarkan Pendekatan Sistem. Jakarta: PT Bumi Aksara.

Hery. (2013). Akuntansi Perusahaan Jasa dan Dagang. Bandung: CV Alfabeta.

Jusup, Al Haryono. (2005). Dasar-dasar Akuntansi Jilid 1. Yogyakarta: Sekolah Tinggi Ilmu Ekonomi YKPN.

Kurniawan, Deni. (2014). Pembelajaran Terpadu Tematik (Teori, Praktik, dan Penilaian). Bandung: Alfabeta.

Lie, Anita. (2008). Cooperative Learning. Jakarta: PT Grasindo.

Martani, Dwi et.al. (2012). Akuntansi Keuangan Menengah. Jakarta: Salemba Empat.

Mulyono. (2008). Teori Pengambilan Keputusan (Theory of Decision Making). Jakarta: Bumi Aksara.

Rasyid, Harun \& Mansyur. (2007). Penilaian Hasil Belajar. Bandung: CVWahana Prima.

Sapriya. (2015). Pendidikan IPS. Bandung: PT Remaja Rosdakarya Offset.

Shoimin, Aris. (2014). 68 Model Pembelajaran Inovatif dalam Kurikulum 2013. Yogyakarta: ArRuzz Media. 
Susanto, Bob. (2015). 25 Pengertian Akuntansi menurut para Ahli Lengkap. [Online]. Tersedia: http://www.Seputarpengetahuan.com /2015/3/pengertian-akuntansi-secaraumum-terlengkap.html.

Syah, Muhibbin (2013). Psikologi Pendidikan dengan Pendekatan Baru. Bandung: PT Remaja Rosdakarya Offset.

Taniredja, Tukiran et. al. (2013). Penelitian Tindakan Kelas untuk Mengembangkan Profesi Guru Praktik, Praktis dan Mudah. Bandung: CV Alfabeta.

Tirta Raharja, Umar \& S.L.La Sulo. (2005). Pengantar Pendidikan. Jakarta: PT. Rineka Cipta.

Zakiyudin. Ais. (2013). Akuntansi Tingkat Dasar Dilengkapi dengan Akuntansi bagi Organisasi Zakat. Jakarta: Mitrawacana Media. 